\title{
Mitochondrial DNA mapping of social-biological interactions in Brazilian Amazonian African-descendant populations
}

\author{
Bruno Maia Carvalho ${ }^{1}$, Maria Cátira Bortolini ${ }^{2}$, Sidney Emanuel Batista dos Santos ${ }^{1}$ \\ and Ândrea Kely Campos Ribeiro-dos-Santos ${ }^{1}$ \\ ${ }^{1}$ Laboratório de Genética Humana e Médica, Instituto de Ciências Biológicas, \\ Universidade Federal do Pará, Belém, Pa, Brazil. \\ ${ }^{2}$ Departamento de Genética, Universidade Federal do Rio Grande do Sul, Porto Alegre, RS, Brazil.
}

\begin{abstract}
The formation of the Brazilian Amazonian population has historically involved three main ethnic groups, Amerindian, African and European. This has resulted in genetic investigations having been carried out using classical polymorphisms and molecular markers. To better understand the genetic variability and the micro-evolutionary processes acting in human groups in the Brazilian Amazon region we used mitochondrial DNA to investigate 159 maternally unrelated individuals from five Amazonian African-descendant communities. The mitochondrial lineage distribution indicated a contribution of $50.2 \%$ from Africans (L0, L1, L2, and L3), 46.6\% from Amerindians (haplogroups A, B, C and D) and a small European contribution of 1.3\%. These results indicated high genetic diversity in the Amerindian and African lineage groups, suggesting that the Brazilian Amazonian African-descendant populations reflect a possible population amalgamation of Amerindian women from different Amazonian indigenous tribes and African women from different geographic regions of Africa who had been brought to Brazil as slaves. The present study partially mapped the historical biological and social interactions that had occurred during the formation and expansion of Amazonian African-descendant communities.
\end{abstract}

Key words: African mtDNA, Amazon population, Amerindian mtDNA, HVS-I.

Received: January 5, 2007; Accepted: June 11, 2007.

\section{Introduction}

The Portuguese settled in the Amazon region between the sixteenth and eighteenth centuries and carried out economic activities targeted at the European market. Extractivism based on Amerindian slave labor initially prevailed but later agriculture and cattle raising was supported by the intense Sub-Sahara African slave trade (Porto, 1938; Bezerra-Neto, 2001). Historical records indicate that about three and a half million captives were brought to Brazil, mainly from western and central Africa (Curtin, 1969; Salzano and Freire-Maia, 1970; Ribeiro, 1995). African slaves were brought to the Brazilian Amazon principally in the second half of the eighteenth century and became the main work force in the region (Conrad, 1985; Salles, 1988; Ribeiro, 1995). Approximately 53,000 slaves disembarked in this area, and by the middle of the nineteenth century the slave population in the Brazilian state of Pará in the Ama-

Send correspondence to Ândrea K.C. Ribeiro-dos-Santos. Laboratório de Genética Humana e Médica, Instituto de Ciências Biológicas, Universidade Federal do Pará, Caixa Postal 8615, Rua Augusto Corrêa 01, Guamá, 66075-970 Belém, Pa, Brazil. E-mail: akely@ufpa.br. zon region was almost 34,000 , of which $49 \%$ were women and 51\% men (Salles, 1988).

Slaves faced precarious living and working conditions in Brazil and their life expectancy was only 10 years after arrival. The most usual response to bad treatment was escaping, with many fugitive slaves founding independent communities called quilombos or mocambos in isolated areas, which are now known as African-descendant or African-derived communities (Ribeiro, 1995; Acevedo and Castro, 1998; Bezerra-Neto, 2001). Over last 20 years, these populations have been investigated by several groups of researchers such as anthropologists, linguists and geneticists, among others, in order to better understand the sociobiological formation and increment of such populations. Genetic studies based on classical genetic polymorphisms helped to reconstruct part of the history of these populations and also provided the first estimates concerning parental contributions, which demonstrated that these groups preserve a predominantly African genetic pool, notwithstanding the European and Amerindian contributions (Schneider et al., 1987; Bortolini et al., 1995, 1998; Guerreiro et al., 1999). 
During the last decade many studies have used lineage markers such as mitochondrial DNA (mtDNA) to describe the genetic variability and evolutionary processes of different world populations. Phylogenetic analyses of mtDNA lineages (matrilineages) have also been published and many geographic-specific haplogroups have been identified (Vigilant et al. 1991; Torroni et al., 1993, 1996; Chen et al., 1995, 2000; Santos et al., 1996; Watson et al., 1996, 1997; Bortolini et al., 1997, 1999; Rando et al., 1998; Bandelt et al., 2001; Pereira et al., 2001; Salas et al., 2002, 2004; Yao et al., 2002; Mishmar et al., 2003; Rosa et al., 2004; Shen et al., 2004).

In this paper we provide information on the mtDNA haplogroup distribution of five African-descendant populations and evaluate the specific social mechanisms active in such communities, the aim being to better understand the genetic variability and the micro-evolutionary processes acting in human groups in the Brazilian Amazon. Additionally, our data were analyzed together with others recently published to determine the phylogeographic composition of the mtDNA lineages of African-descendant populations. We also discuss some aspects of the nature of the Atlantic slave trade to the Brazilian Amazon region.

\section{Material and Methods}

\section{Sample population}

Our population sample consisted of unrelated African-descendants $(\mathrm{n}=159)$ living in five communities located in three states in the Brazilian Amazon region: Trombetas $(\mathrm{n}=32)$, Marajó island $(\mathrm{n}=34)$ and Pitimandeua $(\mathrm{n}=29)$ in Pará state; ii) Tamauari $(\mathrm{n}=31)$ in Maranhão state; and iii) Mazagão $(\mathrm{n}=33)$ in Amapá state. The geographic locations of these communities, self-reported as being based on African-descendants, are shown in Figure 1. All individuals provided their prior informed consent and this research was approved by the Ethical Committee of the Universidade Federal do Pará.

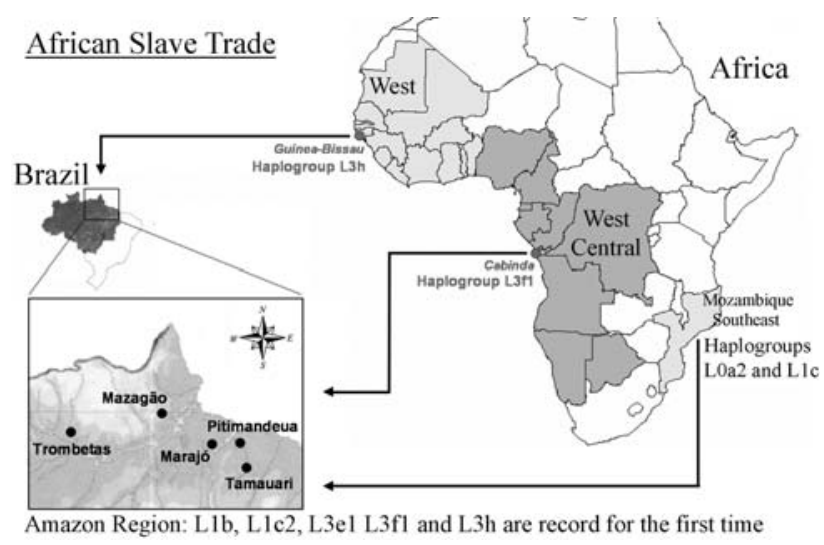

Figure 1 - Geographic localization of the Afro-descendant communities in the Brazilian Amazon region and the African probable origin of some mtDNA lineages observed in this study.

\section{Mitochondrial DNA polymorphisms}

The phenol-chloroform and ethanol methods (Sambrook et al., 1989) were used to extract DNA from whole peripheral blood. After extraction the DNA was quantified in a Gene Quant RNA/DNA spectrophotometer (Amersham Biosciences, UK) and diluted to a working concentration of $100 \mathrm{ng} \mathrm{mL}^{-1}$.

We Initially investigated the $9 \mathrm{bp}$ deletion in region $\mathrm{V}$ of the CoII/tRNAlys intergenic region as well as the 663/Hae III, 13,259/Hinc II and 5,176/Alu I restriction fragment length polymorphisms (RFLP) which define Amerindian haplogroups (A-D) (Hertzberg et al., 1989; Torroni et al., 1992, 1993) along with the association of the 9 bp deletion with the 3,592/Hpa I RFLP which defines the African L0a2b subclade (Chen et al., 2000). Next, we used the L15997 and H16401 primers (Pereira et al., 2000) to amplify the first mitochondrial DNA hypervariable region (HVS-I) of samples from all five populations. The targets and the polymerase chain reaction (PCR) amplified segments were purified with a PureLink kit (Invitrogen, USA). The forward and reverse sequencing reactions were performed with the Big Dye ${ }^{\mathrm{TM}}$ Terminator Cycle Sequence kit (Applied Biosystems, USA). Vertical electrophoresis was performed on $5 \%(\mathrm{w} / \mathrm{v})$ denaturing polyacrylamide gels using ABI prism 377 DNA Sequencer (Applied Biosystems, USA). To better classify some sequences that did not present informative HVS-I mutations for the geographically-specific haplogroups and $\mathrm{Eu}-$ ropeans lineages we also used a further 19 RFLP markers belonging to the $\mathrm{L} 0 \mathrm{a}, \mathrm{L} 1 \mathrm{~b}, \mathrm{~L} 1 \mathrm{c}, \mathrm{L} 3 \mathrm{~b}, \mathrm{~L} 3 \mathrm{~d}, \mathrm{~L} 3 \mathrm{e}, \mathrm{K}, \mathrm{H}, \mathrm{W}, \mathrm{T}$, $\mathrm{X}, \mathrm{U}, \mathrm{V}, \mathrm{I}$ and J haplogroups (Torroni et al., 1996; Alves-Silva et al., 2000; Chen et al., 2000).

The classification of each mtDNA lineage followed the nomenclature suggested for defining the African, Amerindian and European mitochondrial haplogroups (Torroni et al., 1993, 1996; Pereira et al., 2001; Salas et al., 2002, 2004; Mishmar et al., 2003). African mitochondrial haplogroups were characterized as L0a (pro L1a), L1b, L2a; L2b and other L3 haplogroups. Mutations at nucleotide positions (np) 16124, 16278 and 16362 were characterized as haplogroup L3b, and mutations at np 16124 and 16223 were characterized as haplogroup L3d. According to Bandelt et al. (2001), haplogroup L3e subdivides into L3e1 (16223 and 16327), L3e2 (16223 and 16320) and L3e3 (16223 and 16265T). Haplogroup L3f is characterized by transversions at $\mathrm{np}$ 16209 and 16311 (Salas et al., 2002). Sub-clade L3f1 is characterized by mutations at $16209,16218,16256,16292$, and 16311. We classified as haplogroup L3h (Kivisild et al., 2004; Rosa et al., 2004) the haplotype characterized by mutations at np 16129, 16256 and 16362. Mutations at np 16224 and 16311 characterize European haplogroup K (Torroni et al., 1996; Pereira et al., 2000).

\section{Data analysis}

Global analysis was performed with the 159 samples. We carried out Network analysis separately for the Amerin- 
dian and African lineage groups (Figure 2) using the median joining algorithm (Bandelt et al. 1999). Pairwise differences were obtained considering HVS-I for the same lineage groups according to the assumptions of Aris-Brosou and Excoffier (1996) using the DNAsp V 4.10 program (Rozas et al., 2003). Haplotype and nucleotide diversities were estimated using ARLEQUIN 2.0 (Schneider et al., 2000). Since the mtDNA haplogroups are geographically specific, the parental contributions for each population were obtained by direct counting.

\section{Results and Discussion}

Table 1 presents the $85 \mathrm{mtDNA}$ haplotypes identified in the 159 samples from African-descendants defined by 78 variable nucleotides evaluated by network analysis (Figure 2). These HVS-I haplotypes have previously been reported by Ribeiro-dos-Santos et al. (2007) but we have reanalyzed all the haplotypes to better understand the genetic variability and the micro-evolutionary processes in the human groups in the Brazilian Amazon.

The five African-descendant populations investigated showed large genetic diversity and variability. The four main Amerindian haplogroups (A-D) and the African L1, L2, and L3 haplogroups were observed at different frequencies in these populations. The African L0 haplogroup was the least frequent and was observed only in the Trombetas and Curiaú populations, the latter having been previously studied by Ribeiro-dos-Santos et al. (2002).

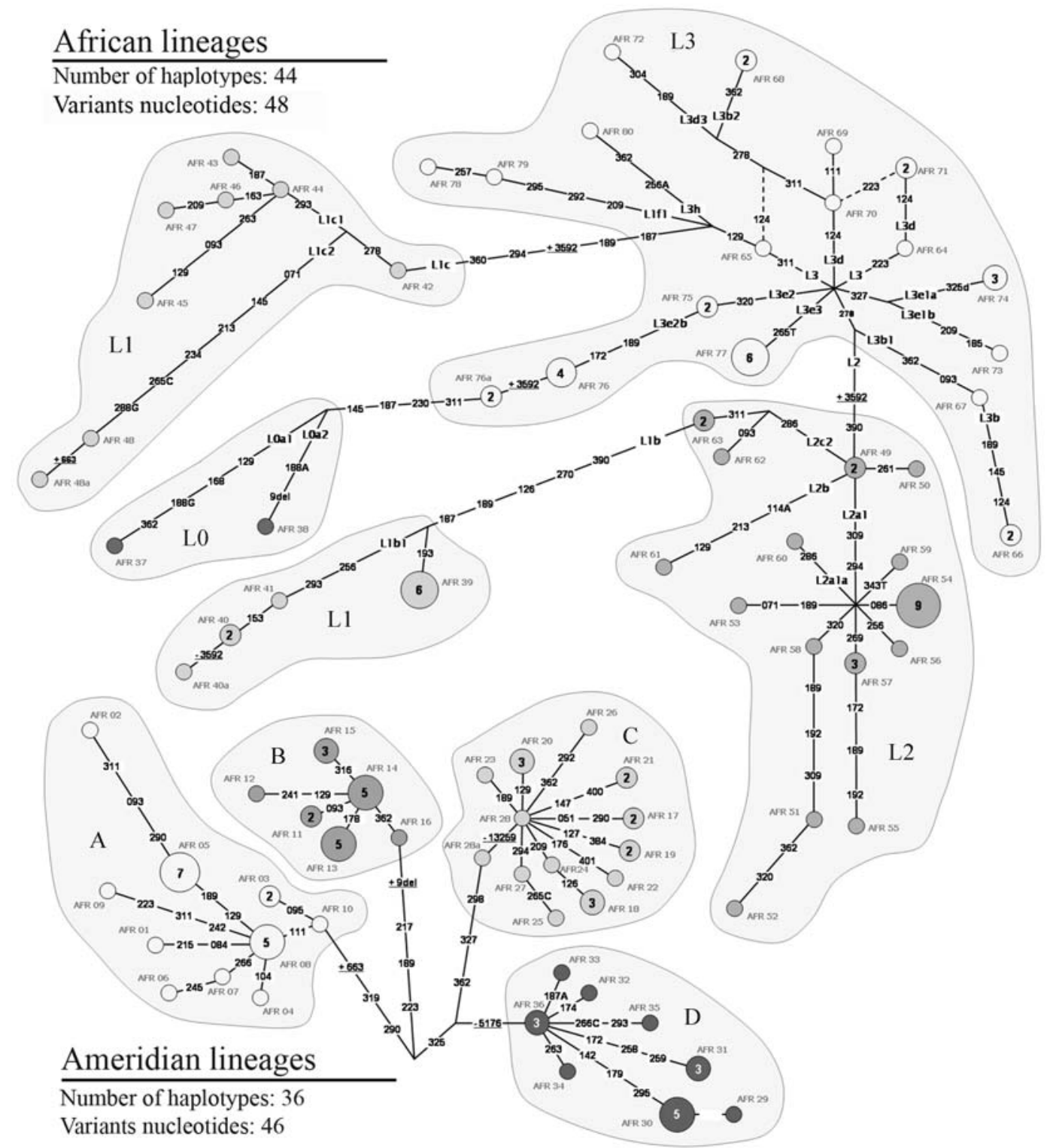

Figure 2 - Networks of African and Amerindian lineage groups. The first hypervariable region (HVS-I) variant nucleotides are indicated along the branches connecting the haplotypes. For the exact nucleotide position 16000 should be added to the numbers. Transversions are indicated by the nitrogen base and deletions by "d". The numbered haplotypes refer to multiple occurrences. The restriction sites and the 9 bp deletion are underlined. 
Table 1 - Haplotypes defined by first hypervariable region (HVS-I) variant nucleotides in samples of Afro-descendant populations from the Brazilian Amazon. Haplotypes characterized only by HVS-I region nucleotide variability. Haplotypes followed by the letter "a" (e.g., AFR 28a) also showed restriction fragment length polymorphism (RFLP) variation and the $9 \mathrm{bp}$ deletion. The population sample consisted of unrelated African-descendants $(\mathrm{n}=159)$ living in five communities located in three states in the Brazilian Amazon region: Trombetas $(\mathrm{n}=32)$, Marajó island $(\mathrm{n}=34)$ and Pitimandeua $(\mathrm{n}=29)$ in Pará state; ii) Tamauari $(\mathrm{n}=31)$ in Maranhão state; and iii) Mazagão $(\mathrm{n}=33)$ in Amapá state. In the 'variable nucleotides' column the numbers indicate variable nucleotides after comparison with the Cambridge (CRS) reference sequence of the HVS-I region, 16000 must be added to these numbers for the exact nucleotide position. Transversions are indicated by the nitrogen base, and deletions by "del". The final classification is given in the last column. Results in parentheses correspond to the initial analysis of three RFLP and the 9 bp deletion. In the haplotype column ' $n$ ' represents the total number of individuals with the cited haplotype, while in the population column it represents the number of individuals per population.

\begin{tabular}{|c|c|c|c|c|c|c|c|}
\hline \multirow[t]{2}{*}{ Haplotypes (n) } & \multicolumn{5}{|c|}{ Population (n) } & \multirow[t]{2}{*}{ Variable nucleotides } & \multirow[t]{2}{*}{ Haplogroups } \\
\hline & TRB & MRJ & PTD & TMR & MAZ & & \\
\hline AFR 01 & & & & 1 & & 084111215223290319362 & $\mathrm{~A}$ \\
\hline AFR 02 & & 1 & & & & 093111129189223311319362 & $\mathrm{~A}$ \\
\hline AFR 03 & 2 & & & & & 095223290319362 & $\mathrm{~A}$ \\
\hline AFR 04 & 1 & & & & & 104111223290319362 & $\mathrm{~A}$ \\
\hline AFR 05 & & 3 & 1 & & 3 & 111129189223290319362 & A \\
\hline AFR 06 & & & & 1 & & 111223245266290319362 & A \\
\hline AFR 07 & & & & 1 & & 111223266290319362 & A \\
\hline AFR 08 & 1 & 1 & 1 & 1 & 1 & 111223290319362 & $\mathrm{~A}$ \\
\hline AFR 09 & & & & 1 & & 111242290311319362 & $\mathrm{~A}$ \\
\hline AFR 10 & 1 & & & & & 223290319362 & A \\
\hline Total for $\mathrm{A}(\mathrm{n}=21)$ & 5 & 5 & 2 & 5 & 4 & & \\
\hline AFR 11 & & & & & 2 & 093189217 & B (+del.9pb) \\
\hline AFR 12 & & & & & 1 & 129189217241 & B (+del.9pb) \\
\hline AFR 13 & & & 1 & & 4 & 178189217 & B (+del.9pb) \\
\hline AFR 14 & & & 2 & 1 & 2 & 189217 & B (+del.9pb) \\
\hline AFR 15 & 1 & 2 & & & & 189217316 & B (+del.9pb) \\
\hline AFR 16 & & & & & 1 & 189217362 & B (+del.9pb) \\
\hline Total for B $(n=17)$ & 1 & 2 & 3 & 1 & 10 & & \\
\hline AFR 17 & 2 & & & & & 051223325327 & $\mathrm{C}$ \\
\hline AFR 18 & & & & 3 & & 126209223298325327 & $\mathrm{C}$ \\
\hline AFR 19 & & & 1 & 1 & & 127223298325327384 & $\mathrm{C}$ \\
\hline AFR 20 & 1 & 2 & & & & 129223298325327 & $\mathrm{C}$ \\
\hline AFR 21 & & & 1 & 1 & & 147223298325327400 & $\mathrm{C}$ \\
\hline AFR 22 & & & & 1 & & 176223298325327401 & $\mathrm{C}$ \\
\hline AFR 23 & & & & & 1 & 189223298325327 & $\mathrm{C}$ \\
\hline AFR 24 & & & & 1 & & 209223298325327 & $\mathrm{C}$ \\
\hline AFR 25 & & & & & 1 & 223 265C 294298325327 & $\mathrm{C}$ \\
\hline AFR 26 & & & & 1 & & 223292298325327362 & $\mathrm{C}$ \\
\hline AFR 27 & & & 1 & & & 223294298325327 & $\mathrm{C}$ \\
\hline AFR 28 & & & & 1 & & 223298325327 & $\mathrm{C}$ \\
\hline AFR 28a & 1 & & & & & 223298325327 & $\mathrm{C}(+13.259 /$ HincII $)$ \\
\hline Total for $C(n=20)$ & 4 & 2 & 3 & 9 & 2 & & \\
\hline AFR 29 & 1 & & & & & 142179192223295325362 & $\mathrm{D}$ \\
\hline AFR 30 & 3 & 1 & & & 1 & 142179223295325362 & $\mathrm{D}$ \\
\hline AFR 31 & & 3 & & & & 172223258259325362 & $\mathrm{D}$ \\
\hline AFR 32 & & & & & 1 & 174223325362 & $\mathrm{D}$ \\
\hline AFR 33 & & & & 1 & & 187A 223325362 & $\mathrm{D}$ \\
\hline AFR 34 & & 1 & & & & 223263325362 & $\mathrm{D}$ \\
\hline AFR 35 & & 1 & & & & 223 266G 293325362 & $\mathrm{D}$ \\
\hline AFR 36 & & & 1 & 1 & 1 & 223325362 & $\mathrm{D}$ \\
\hline Total for $\mathrm{D}(\mathrm{n}=16)$ & 4 & 6 & 1 & 2 & 3 & & \\
\hline
\end{tabular}


Table 1 (cont.)

\begin{tabular}{|c|c|c|c|c|c|c|c|}
\hline \multirow[t]{2}{*}{ Haplotypes (n) } & \multicolumn{5}{|c|}{ Population (n) } & \multirow[t]{2}{*}{ Variable nucleotides } & \multirow[t]{2}{*}{ Haplogroups } \\
\hline & TRB & MRJ & PTD & TMR & MAZ & & \\
\hline AFR 37 & 1 & & & & & 129148168172187 188G 189223230311320362 & L0a1 \\
\hline AFR 38 & 1 & & & & & $148172187188 \mathrm{~A} 189223230311320$ & L0a2 (+del.9pb) \\
\hline Total for $\mathrm{L} 0(\mathrm{n}=2)$ & 2 & 0 & 0 & 0 & 0 & & \\
\hline AFR 39 & & 6 & & & & 126187189193223264270278311 & $\mathrm{~L} 1 \mathrm{~b}$ \\
\hline AFR 40 & 2 & & & & & 126153187189223256264270278293311 & L1b1 \\
\hline AFR 40a & 1 & & & & & 126153187189223256264270278293311 & L1b1 (-3.592/HpaI) \\
\hline AFR 41 & 1 & & & & & 126187189223256264270278293311 & L1b1 \\
\hline AFR 42 & & 1 & & & & 129187189223294311360 & L1c \\
\hline AFR 43 & & & & & 1 & 129187189223278293294311360 & L1c1 \\
\hline AFR 44 & & & & & 1 & 093187189223263278293294311360 & L1c1 \\
\hline AFR 45 & & & & 1 & & 129163187189209223278293294311360 & L1c1 \\
\hline AFR 46 & & & 1 & & & 129163187189223278293294311360 & L1c1 \\
\hline AFR 47 & & & & & 1 & 129189223274278293294311360 & L1c1a \\
\hline AFR 48 & & & 1 & & & 071129145187189213223234 265C 278 286G 294311360 & L1c2 \\
\hline AFR 48a & & & 1 & & & 071129145187189213223234 265C 278 286G 294311360 & L1c2 (+663/HaeIII) \\
\hline Total for L1 $(\mathrm{n}=18)$ & 4 & 7 & 3 & 1 & 3 & & \\
\hline AFR 49 & & & 1 & & & 223261278390 & L2 \\
\hline AFR 50 & 1 & & & & 1 & 223278390 & $\mathrm{~L} 2$ \\
\hline AFR 51 & 1 & & & & & 189192223278294320390 & L2a \\
\hline AFR 52 & & 1 & & & & 189192223278294362390 & $\mathrm{~L} 2 \mathrm{a}$ \\
\hline AFR 53 & & 1 & & & & 071189223278294309390 & L2a1 \\
\hline AFR 54 & & 7 & & 2 & & 086223278294309390 & L2a1 \\
\hline AFR 55 & & & & & 1 & 172189192223269278294309390 & L2a1 \\
\hline AFR 56 & & & 1 & & & 223256278294309390 & L2a1 \\
\hline AFR 57 & & & & & 3 & 223269278294309390 & L2a1 \\
\hline AFR 58 & & & 1 & & & 223278294309320390 & L2a1 \\
\hline AFR 59 & & & & & 1 & 223278294309343 T 390 & L2a1 \\
\hline AFR 60 & & & 1 & & & 223278286294309390 & L2a1a \\
\hline AFR 61 & & & & 1 & & 114A 129213223278390 & $\mathrm{~L} 2 \mathrm{~b}$ \\
\hline AFR 62 & & & 1 & & & 093223264278390 & $\mathrm{~L} 2 \mathrm{c} 2$ \\
\hline AFR 63 & & & 2 & & & 223264278311390 & $\mathrm{~L} 2 \mathrm{c} 2$ \\
\hline Total for L2 $(\mathrm{n}=27)$ & 2 & 9 & 7 & 3 & 6 & & \\
\hline AFR 64 & & & & 1 & & 223311 & L3 \\
\hline AFR 65 & & & & & 1 & CRS & L3 \\
\hline AFR 66 & & & & 2 & & 093124145189223278362 & $\mathrm{~L} 3 \mathrm{~b}$ \\
\hline AFR 67 & & & 1 & & & 093223278362 & L3b1 (+10.084/TaqI $)$ \\
\hline AFR 68 & 1 & & & & 1 & 124223278311362 & $\mathrm{~L} 3 \mathrm{~b} 2$ \\
\hline AFR 69 & & & & & 1 & 111124223 & L3d \\
\hline AFR 70 & & & 1 & & & 124 & L3d \\
\hline AFR 71 & & & & 2 & & 124223 & L3d \\
\hline AFR 72 & & & & 1 & & 124189223278304311 & $\mathrm{~L} 3 \mathrm{~d} 3$ \\
\hline AFR 73 & & & & 1 & & 185209223327 & L3ela \\
\hline AFR 74 & 3 & & & & & $223325 \mathrm{del} 327$ & L3e1b \\
\hline AFR 75 & & & 2 & & & 223320 & $\mathrm{~L} 3 \mathrm{e} 2$ \\
\hline AFR 76 & & 1 & 3 & & & 172189223320 & $\mathrm{~L} 3 \mathrm{e} 2 \mathrm{~b}$ \\
\hline AFR 76a & & 1 & 1 & & & 172189223320 & $\mathrm{~L} 3 \mathrm{e} 2 \mathrm{~b}(+3.592 / H p a \mathrm{I})$ \\
\hline
\end{tabular}


Table 1 (cont.)

\begin{tabular}{|c|c|c|c|c|c|c|c|}
\hline \multirow[t]{2}{*}{ Haplotypes (n) } & \multicolumn{5}{|c|}{ Population (n) } & \multirow[t]{2}{*}{ Variable nucleotides } & \multirow[t]{2}{*}{ Haplogroups } \\
\hline & TRB & MRJ & PTD & TMR & MAZ & & \\
\hline AFR 77 & 4 & & 2 & & & $223265 \mathrm{~T}$ & L3e3 \\
\hline AFR 78 & 1 & & & & & 129209223257292295311 & L3f1 \\
\hline AFR 79 & 1 & & & & & 129209223292295311 & L3f1 \\
\hline AFR 80 & & & & 1 & & $129223256 \mathrm{~A} 311362$ & L3h \\
\hline Total for L3 $(\mathrm{n}=33)$ & 10 & 2 & 10 & 8 & 3 & & \\
\hline AFR 81 & & & & & 1 & 224311322 & $\begin{array}{l}\text { K (+10.394/Dde I, - } \\
\text { 9.052/HaeII) }\end{array}$ \\
\hline AFR 82 & & 1 & & & & 093224311 & $\begin{array}{l}\text { K (+10.394/Dde I, - } \\
\text { 9.052/HaeII) }\end{array}$ \\
\hline Total for K $(\mathrm{n}=2)$ & 0 & 1 & 0 & 0 & 1 & & \\
\hline AFR 83 & & & & 1 & & 093223355 & Other \\
\hline AFR 84 & & & & & 1 & 153298 & Other \\
\hline AFR 85 & & & & 1 & & 223288 & Other \\
\hline Total for Other $(\mathrm{n}=3)$ & 0 & 0 & 0 & 2 & 1 & & \\
\hline
\end{tabular}

Similar genetic diversity values were observed when the average nucleotide differences $(\mathrm{k})$ and the haplotype diversity results (Hd) of Amazonian African-descendant Brazilians were compared with those of African groups from different regions of Africa (Mateu et al., 1997; Salas et al. 2004) (Table 2). The same occurred when the genetic diversity values of the Amerindian stock identified in the African-descendant populations were compared with those of isolated indigenous communities of the Brazilian Amazon. Since these African-descendant populations have resulted from the miscegenation of Africans and Amerindians our results indicate that the remaining quilombo communities of the Amazon region are possibly an important reservoir of African and Amazonian indigenous mtDNA variability.

\section{Pairwise difference and genetic diversity}

Pairwise analyses of nucleotidic differences relative to HVS-I of the samples obtained from the 159 African- descendants of the Amazon region and the Amerindian (74 samples) and African (80 samples) lineage groups were performed separately. The charts showed a normal distribution curves, although the Tajima test results were nonsignificant $(p>0.1)$. The average numbers of nucleotide differences for the Amerindian and African lineage groups (see Table 2) were similar to those reported for other Brazilian Amazonian Amerindian populations (Ward et al., 1991; Santos et al., 1996) and native sub-Saharan African populations (Salas et al. 2002, 2004) as well as to haplotype and nucleotide diversity results.

\section{Mitochondrial DNA variability and parental contribution estimates African fraction}

Approximately half of the samples $(80 / 159,50.3 \%)$ were from African maternal lineages, which had the widest geographical contribution of the samples studied. The African lineage haplogroups detected by us were as follows:

Table 2 - Genetic diversity in Afro-descendant populations from the Brazilian Amazon. The Table shows number of samples (n), number of variable nucleotides $(\mathrm{S})$, number of haplotypes $(\mathrm{h})$, genetic diversity $\left(\mathrm{H}_{\mathrm{d}}\right)$, standard deviation of the genetic diversity $\left(\mathrm{SD}_{\mathrm{Hd}}\right)$; nucleotide diversity $(\pi)$, standard deviation of the nucleotide diversity $\mathrm{SD}_{\pi}$, average pairwise differences (k) and Tajima test value (D). NS = not significant.

\begin{tabular}{lcccccccccc}
\hline Population & $\mathrm{n}$ & $\mathrm{S}$ & $\mathrm{h}$ & $\mathrm{H}_{\mathrm{d}}$ & $\mathrm{SD}_{\mathrm{Hd}}$ & $\pi$ & $\mathrm{SD}_{\pi}$ & $\mathrm{k}$ & $\mathrm{D}$ \\
\hline Tamauari & 31 & 45 & 26 & 0.987 & 0.012 & 0.02033 & 0.00155 & 7,258 & $-1,36459 \mathrm{NS}$ \\
Trombetas & 32 & 40 & 21 & 0.966 & 0.016 & 0.02103 & 0.00210 & 7,486 & $-0,96574 \mathrm{NS}$ \\
Marajó & 34 & 38 & 16 & 0.920 & 0.027 & 0.02362 & 0.00076 & 8,433 & $-0,33288 \mathrm{NS}$ \\
Mazagão & 33 & 36 & 24 & 0.973 & 0.015 & 0.01980 & 0.00132 & 7,068 & $-0,73143 \mathrm{NS}$ \\
Pitimandeua & 29 & 38 & 21 & 0.973 & 0.017 & 0.02015 & 0.00220 & 7,192 & $-1,08894 \mathrm{NS}$ \\
Afro-descendants & 159 & 78 & 85 & 0.984 & 0.003 & 0.02098 & 0.00076 & 7,668 & $-1,56021 \mathrm{NS}$ \\
Amerindian fraction & 74 & 46 & 36 & 0.974 & 0.007 & 0.01823 & 0.00055 & 6,509 & $-1,06350 \mathrm{NS}$ \\
African fraction & 80 & 48 & 44 & 0.969 & 0.008 & 0.02088 & 0.00110 & 7,434 & $-0,95293 \mathrm{NS}$ \\
\hline
\end{tabular}


L0, the least frequent $(2 / 80,2.5 \%)$ and containing subclades (also called variants) L0a1 and L0a2; L1, moderately frequent $(18 / 80,22.5 \%)$ and containing haplogroups L1b and L1c; L2, the second most frequent (27/80, 33.8\%) and containing haplogroups L2a, L2b, and L2c; and L3, the most frequent $(33 / 80,41.2 \%)$ and containing sub-clades L3b, L3d, L3e, L3f and L3h.

The L0a1 sub-clade observed in our study is apparently absent from the northern region of the Brazilian Amazon (Silva-Junior et al., 2006) but was previously identified in the African-descendant Curiaú population in the Brazilian Amazon (Ribeiro-dos-Santos et al., 2002) and has also been described in populations from southeastern and southwestern Africa (Plaza et al., 2004; Salas et al., 2004; Beleza et al., 2005). The L0a2 sub-clade HVS-I mutations detected by us, also identified by the $9 \mathrm{bp}$ deletion in region $\mathrm{V}$, have been reported at a low frequency of $\sim 4.5 \%$ in Brazil (SilvaJunior et al., 2006) but at $19 \%$ in Mozambique in southeastern Africa (Salas et al., 2002).

In our study, 10 of the African-descendants belonged to sub-clade L1b, the third most frequent haplogroup $(10 / 80,12.5 \%)$, which has been reported to be almost restricted to West Africa (Salas et al., 2002, 2004). However, we found only eight lineages belonging to haplogroup L1c, which is a marker from western central Africa (Salas et al., 2004; Beleza et al., 2005). None of the HVS-I haplotypes belonging to the L1c haplogroup have been observed in Angola (Plaza et al., 2004) but some have been found in Cabinda in western central Africa and in Mozambique. The L1c haplogroup, and more specifically L1c2, L0a1, L3e1 and $\mathrm{L} 3 \mathrm{e} 2$, are known to be frequent in African descendants from different regions of Brazil (Alves-Silva et al., 2000; Silva-Junior et al., 2006). However, we found that the most frequent mtDNA lineages of African descendant in the Brazilian Amazon belonged to haplogroups L3e (19/80, 23.7\%), L2a (18/80, 22.5\%) and L1b (10/80, 12.5\%), these three haplogroups together being found in a total of 47 individuals of the 80 individuals of African maternal lineage $(58.7 \%)$. These results suggest the existence of dissimilarities in the geographical distribution of African lineages in Brazil, which may be directly associated with slave trade practices adopted in the eighteenth and nineteenth centuries.

We also found that of the two sub-clade L1c2 lineages detected, both with the same haplotype, one (AFR 48a) presented the Hae III restriction site at position 663 , which is the marker for Amerindian lineages in haplogroup A. The isolated occurrence of this Amerindian mutation in a lineage of African background might indicate recurrent mutation events, as described for Amerindian lineages by various authors (Bailliet et al., 1994; Santos et al., 1996; Torres et al., 2006). Because this lineage was of certain African origin and was the only one to exhibit a marker of a different geographic group (i.e., an Amerindian marker) we classified it as a complex haplotype.
In our study, there were low frequencies of some other haplogroups and sub-clades, such as L1c2, L2b, L3f1 and L3h. Sub-clade L3f1 only matches the lineages described in the central African Cabinda population (Beleza et al., 2005). The haplotype that represented haplogroup L3h (AFR 80) matched lineages described in the western African region of Guinea-Bissau where it was first described (Rosa et al., 2004). The L1b, L1c2, L3e1, L3f1 and L3h sub-clades have not previously been reported in the Brazilian Amazon (Alves-Silva et al., 2000; Silva-Junior et al., 2006). It is important to emphasize that this is the first report of the L3h haplogroup in Brazil, although it has been reported in Guinea-Bissau in western Africa and Ethiopia in eastern Africa (Kivisild et al., 2004; Rosa et al., 2004) (Figure 1).

Regarding slave trade practices, historical data suggests that $30 \%$ of the Africans brought to the Brazilian Amazon came from western Africa (Klein, 2002). Although most of the mtDNA haplogroups and sub-clades are geographically nonspecific, some groups have different distributions in Sub-Saharan Africa. For example, if we consider haplogroups L1b, L2c and L3d as markers from western Africa (Bandelt et al., 2001; Salas et al., 2004) it is possible to estimate that the contribution made by this region to the formation of contemporary Brazilian Amazonian Africandescendant populations is about $25 \%$. On the other hand, other haplogroups or sub-clades are more frequent in western, central and southeastern Africa, regions related to the major Bantu linguistic branch. Studies of hemoglobin S related polymorphisms in Brazilian Amazonian Africandescendant populations suggest a Bantu contribution of approximately 45\% (Pante-de-Souza et al., 1998). Adopting L0a, L2a, L1c, L3e1, and L3e2 as representative Bantu markers (Bandelt et al., 1995; Watson et al., 1997; AlvesSilva et al., 2000) leads to an estimate of 50\%. Therefore, the data obtained by us are in agreement with the historical sources and other previously published biological data.

\section{Amerindian fraction}

The second most important contribution to the mtDNA lineages of African-descendant populations were Amerindian-descendant (74/159, 46.6\%). The four major Amerindian haplogroups (A, B, C and D) were well characterized by RFLP and the HVS-I region. Haplogroups A and $\mathrm{C}$ were the most frequent and presented similar distributions, followed by haplogroups B and D (Figure 2).

Haplogroup A lineages were defined by the 663/Hae III marker in association with the transitions at np 16111, 16290, and 16319 in the HVS-I region (Torroni et al. 1993). The mutation at np 16111, identified in Amerindian lineages, was not detected in two of the haplotypes (see Table 1). Similarly, Santos et al. (1996) also reported the absence of this transition in five Brazilian Amazonian Amerindian samples belonging to the same haplogroup. The $9 \mathrm{bp}$ deletion and the absence of the 3592/Hpa I restriction 
site occurred in all the 17 sequences identified for haplogroup B (Hertzberg et al. 1989; Torroni et al. 1993). Curiously, we found that in haplogroup C (present in 20 of our samples) the 13259/Hinc II site occurred in one sequence (AFR 28a), this also having been reported in other southern Amazonian Brazilian Amerindian populations by Santos et al. (1996) and Bailliet et al. (1994). A recent study of Colombian Amerindians (Torres et al. 2006) reported a haplogroup $\mathrm{C}$ revertant lineage (recurrent mutation recreated +13259 Hinc II) with the same HVS-I haplotype as that identified by us in lineage AFR 28a. Own genetic structure analyses are consistent with reverse mutation at an early stage during the tribalization process.

We found that haplogroup D was the least frequent haplogroup in African descendants from the Brazilian Amazon. All 16 samples classified in this group were marked by the absence of the $5176 /$ Alu $\mathrm{I}$ site. The $\mathrm{T} \rightarrow \mathrm{C}$ transition at site 16325 of HVS-I identified in Amerindian lineages of haplogroup D in Native Americans was observed in all haplotypes (Ward et al., 1991; Torroni et al., 1993; Santos et al. 1996).

Amerindian lineage groups have been detected in Brazilian Amazon African-descendant communities by classical genetic analysis, which detected 14.7\% Amerindian lineage groups, and molecular genetic analysis, which detected 19.1\% Amerindian lineage groups (Table 3). However, the mtDNA data revealed an average Amerindian contribution of $50 \%$ in nine African-descendant populations located in former slave settlements the Brazilian Amazon. Different genetic markers (e.g., nuclear DNA and Y-DNA) may have underestimated the assimilation of the indigenous element in the formation of African-descendant communities. Alternatively, the Amerindian contribution may have occurred through a larger introgression from Amerindian women than from Amerindian men.

Table 3 - Estimates of parental contributions for African-derived populations from the Brazilian Amazon, considering uniparental and biparental genetic markers.

\begin{tabular}{|c|c|c|c|c|}
\hline $\begin{array}{l}\text { Genetic system } \\
\text { and population }\end{array}$ & African & Amerindian & European & References \\
\hline \multicolumn{5}{|c|}{ Classical polymorphism } \\
\hline Cajueiro & 0.674 & 0.000 & 0.326 & Bortolini et al. (1999) \\
\hline Cametá & 0.480 & 0.341 & 0.179 & Bortolini et al. (1999) \\
\hline Curiaú & 0.736 & 0.000 & 0.264 & Guerreiro et al. (1999) \\
\hline Pacoval & 0.443 & 0.283 & 0.274 & Guerreiro et al. (1999) \\
\hline Trombetas & 0.620 & 0.110 & 0.270 & Schneider et al. (1987) \\
\hline Average & 0.590 & 0.147 & 0.263 & \\
\hline \multicolumn{5}{|l|}{ Nuclear DNA } \\
\hline Cajueiro & 0.488 & 0.250 & 0.262 & Bortolini et al. (1999) \\
\hline Cametá & 0.534 & 0.224 & 0.242 & Bortolini et al. (1999) \\
\hline Trombetas & 0.576 & 0.099 & 0.325 & Bortolini et al. (1999) \\
\hline Average & 0.533 & 0.191 & 0.276 & \\
\hline \multicolumn{5}{|l|}{ Y-markers } \\
\hline Cajueiro & 0.780 & 0.000 & 0.240 & Bortolini et al. (1999) \\
\hline Cametá & 0.280 & 0.180 & 0.540 & Bortolini et al. (1999) \\
\hline Curiaú & 0.570 & 0.060 & 0.370 & Ribeiro-dos-Santos et al. (2002) \\
\hline Trombetas & 0.840 & 0.030 & 0.130 & Bortolini et al. (1999) \\
\hline Average & 0.616 & 0.064 & 0.320 & \\
\hline \multicolumn{5}{|c|}{ Mitochondrial DNA } \\
\hline Cajueiro & 0.700 & 0.300 & 0.000 & Bortolini et al. (1999) \\
\hline Cametá & 0.400 & 0.600 & 0.000 & Bortolini et al. (1999) \\
\hline Curiaú & 0.523 & 0.473 & 0.000 & Ribeiro-dos-Santos et al. (2002) \\
\hline Marajó & 0.530 & 0.440 & 0.030 & Present study \\
\hline Mazagão & 0.364 & 0.576 & 0.030 & Present study \\
\hline Pitimandeua & 0.690 & 0.310 & 0.000 & Present study \\
\hline Tamauari & 0.387 & 0.548 & 0.000 & Present study \\
\hline Trombetas-I & 0.340 & 0.660 & 0.000 & Bortolini et al. (1999) \\
\hline Trombetas-II & 0.563 & 0.437 & 0.000 & Present study \\
\hline Average & 0.500 & 0.482 & 0.018 & \\
\hline
\end{tabular}


The high mtDNA estimate of Amerindian lineages in the composition of these communities was unexpected because there are no historical data on significant sexual interaction between African slaves and other ethnic groups in quilombo communities. However, the settlement of South America, and the Brazilian Amazon in particular, has involved complex ethnic-social interactions, especially when it comes to pre-existing Amerindian societies. Settlement has resulted in the formation of genetically mixed urban populations, with Alves-Silva et al. (2000) having demonstrated that $54 \%$ of the mtDNA lineages of individuals from northern Brazil who considered themselves white have an Amerindian descent. Furthermore, Santos et al. (1999) investigated the urban populations of Belém, the capital of the Brazilian state of Pará, and observed a high Amerindian matrilineal contribution of $57 \%$.

The presence of Amerindian lineages in trihybrid urban populations in the Brazilian Amazon has resulted from
Portuguese policy in the sixteenth and seventeenth centuries that encouraged marriages between Portuguese settlers and Amerindian women (Cruz, 1973, Salles, 1988). Since historical records concerning Amerindian miscegenation with African-descendant populations are scarce, we suggest that the "Amerindian-African" union results from a survival and social resistance strategy against the slavery policy adopted in Brazil until the mid nineteenth century.

\section{European and other fractions}

European lineages represented the smallest contribution, being detected in only two samples (1.3\%). Haplogroup K occurred in Mazagão in Amapá state and Marajó island in Pará state and was defined after the analyses of 23 RFLP ( 9 bp deletion) and the sequencing of the first hypervariable region (Table 4). The participation of European groups in the formation of African-descendant communities has not been reported in historical records. Therefore,

Table 4 - Haplogroup classification on five individuals from the Brazilian Amazon Afro-descendant communities of Mazagão (denominated as samples "A" and "B"), Marajó (denominated as sample "C") and Tamauari (denominated as samples "D" and "E"). The classification was based on screening for 23 restriction fragment length polymorphisms (RFLP) and the 9 bp deletion plus the sequencing of the first hypervariable region (HVS-I). For the exact nucleotide position of the HSVI 16000 should bee added to the value for each group.

\begin{tabular}{|c|c|c|c|c|c|}
\hline \multirow[t]{2}{*}{ Polymorphism } & \multicolumn{5}{|c|}{ Population } \\
\hline & Mazagão (sample A) & Marajó (sample C) & Tamauari (sample D) & Tamauari (sample E) & Mazagão (sample B) \\
\hline \multicolumn{6}{|l|}{ RFLP } \\
\hline $5176 /$ Alu I & + & + & + & + & + \\
\hline 663 / Hae III & - & - & - & - & - \\
\hline 13259 / Hinc II & + & + & + & + & + \\
\hline 3592 / Hpa I & - & - & - & - & - \\
\hline 1715 / Dde I & - & - & - & - & - \\
\hline 2349 / Mbo I & - & - & - & - & - \\
\hline 7055 / Alu I & + & + & + & + & + \\
\hline 9070 / Taq I & - & - & - & - & - \\
\hline 8616 / Mbo I & + & + & + & + & + \\
\hline 10084 / Taq I & - & - & - & - & - \\
\hline 10394 / Dde I & + & + & - & - & - \\
\hline 11641 / Hae III & - & - & - & - & - \\
\hline $12810 / R s a \mathrm{I}$ & - & - & - & - & - \\
\hline 4577 / Nla III & + & + & + & + & + \\
\hline 4529 / Hae II & + & + & + & + & + \\
\hline 7025 / Alu I & + & + & + & + & + \\
\hline 8249 / Ava II & - & - & - & - & - \\
\hline 8994 / Hae III & + & + & + & + & + \\
\hline 9052 / Hae II & - & - & - & - & - \\
\hline 10028 / Alu I & + & + & + & + & + \\
\hline 12308 / Hinf I & + & + & + & + & + \\
\hline 13366 / BamH I & - & - & - & - & - \\
\hline 13704 / BstN I & + & + & + & + & + \\
\hline $9 \mathrm{bp}$ deletion & - & - & - & - & - \\
\hline HVS-I variable nucleotides & 224311322 & 093224311 & 093223355 & 153298 & 223288 \\
\hline Result & $\mathrm{K}$ & $\mathrm{K}$ & Inconclusive & Inconclusive & Inconclusive \\
\hline
\end{tabular}


such lineages may have resulted from recent interethnic miscegenation.

Even though the techniques used by us were sophisticated, the classification of three Tamauari and Mazagão lineages (AFR 83, 84, and 85) representing $1.9 \%$ of the total sample, remained inconclusive (Table 1).

According to the results observed, the present study partially mapped the social-biological interactions that had occurred during the formation and expansion of Amazonian African-descendant communities. The mtDNA approach reveals that these populations congregate two main genetic backgrounds: African and Native American lineages. Our results also indicate that these communities are an important reservoir of mtDNA variability and diversity for these human geographic groups.

\section{Acknowledgments}

The authors thank the Afro-descendants who donated samples and enabled this study to be carried out. This study was supported by the Brazilian agencies Financiadora de Estudos e Projetos (FINEP), Projeto Milênio de Conselho Nacional de Desenvolvimento Científico e Tecnológico (CNPq), Coordenação de Aperfeiçoamento de Pessoal de Nível Superior (CAPES), and Universidade Federal do Pará (UFPA). The authors would like to thank Ana Cecília Feio dos Santos for her contribution.

\section{References}

Alves-Silva J, Santos MS, Guimarães PEM, Ferreira ACS, Bandelt HJ, Pena SDJ and Prado VF (2000) The ancestry of Brazilian mtDNA lineages. Am J Hum Genet 67:444-461.

Aris-Brosou S and Excoffier L (1996) The impact of population expansion and mutation rate heterogeneity on DNA sequence polymorphisms. Mol Biol Evol 13:494-504.

Acevedo R and Castro E (1998) Negros do Trombetas. Guardiães de Mata e Rios. Cejup, Belém, 262 pp.

Bailliet G, Rothhammer F, Carnese FR, Bravi CM and Bianchi NO (1994) Founder mitochondrial haplotypes in Amerindian populations. Am J Hum Genet 55:27-33.

Bandelt HJ, Forster P, Sykes BC and Richards MB (1995) Mitochondrial portraits of human populations using median networks. Genetics 141:743-753.

Bandelt HJ, Forster P and Röhl A (1999) Median-joining networks for inferring intraspecific phylogenies. Mol Biol Evol 16:37-48

Bandelt HJ, Lahermo P, Richards M and Macaulay V (2001) Detecting errors in mtDNA data by phylogenetic analysis. Int $\mathrm{J}$ Legal Med 115:64-69.

Beleza S, Gusmão L, Amorim A, Carracedo A and Salas A (2005) The genetic legacy of western Bantu migrations. Hum Genet 117:366-375.

Bezerra-Neto JM (2001) Escravidão Negra na Amazônia (Séculos XVII - XIX). Paka-tatu, Belém, 127 pp.

Bortolini MC, Weimer TA, Salzano FM, Callegari-Jacques SM, Schneider H, Layrisse Z and Bonatto SL (1995) Evolutionary relationships between black South American and African populations. Hum Biol 67:547-559.
Bortolini MC, Zago MA, Salzano FM, Silva-Junior WA, Bonatto SL, Silva MC and Weimer TA (1997) Evolutionary and anthropological implications of mitochondrial DNA variation in African Brazilian populations. Hum Biol 69:141-159.

Bortolini MC, Silva-Junior WA, Weimer TA, Zago MA, Guerra DC, Schneider MP, Layrisse Z, Castellano HM and Salzano FM (1998) Protein and hypervariable tandem repeat diversity in eight African-derived South American populations: Inferred relationships do not coincide. Hum Biol 70:443461.

Bortolini MC, Silva-Junior WA, Guerra DC, Remonatto G, Mirandola R, Hutz MH, Weimer TA, Silva MCBO, Zago MA and Salzano FM (1999) African-derived South American populations: A history of symmetrical and asymetrical matings according to sex revealed bybi- and uni-parental genetics markers. Am J Hum Biol 11:551-563.

Chen YS, Torroni A, Excoffier L, Santachiara-Benerecetti AS and Wallace DC (1995) Analysis of mtDNA variation in African populations reveals the most ancient of all human continent-specific haplogroups. Am J Hum Genet 57:133-149.

Chen YS, Olckers A, Schurr TG, Kogelnik AM, Huoponen K and Wallace DC (2000) mtDNA variation in the South African Kung and Khwe- and their genetic relationships to other African populations. Am J Hum Genet 66:1362-1383.

Conrad RE (1985) Tumbeiros: O Tráfico de Escravos para o Brasil. Brasiliense, São Paulo, 219 pp.

Cruz E (1973) História do Pará. Governo do Estado do Pará, Belém, $210 \mathrm{pp}$.

Curtin PD (1969) The Atlantic Slave Trade: A Census. The University of Wisconsin, Milwaukee, $457 \mathrm{pp}$.

Guerreiro JF, Ribeiro-dos-Santos AKC, Santos EJM, Vallinoto ACR, Cayres-Vallinoto IMV, Aguiar GFS and Santos SEB (1999) Genetical-demographic data from two Amazonian populations composed of descendants of African slaves: Pacoval and Curiaú. Genet Mol Biol 22:163-167.

Hertzberg M, Mickleson KN, Serjeantson SW, Prior JF and Trent RJ (1989) An Asian-specific 9-bp deletion of mitochondrial DNA is frequently found in Polynesians. Am J Hum Genet 44:504-510.

Kivisild T, Reidla M, Metspalu E, Rosa A, Brehm A, Pennarun E, Parik J, Geberhiwot T, Usanga E and Villems R (2004) Ethiopian mitochondrial DNA heritage: Tracking gene flow across and around the gate of tears. Am J Hum Genet 75:752-770.

Klein HS (2002) As origens africanas dos escravos brasileiros. In: Pena SDJ (ed) Homo brasilis: Aspectos Genéticos, Lingüísticos, Históricos e Sócio-Antropológicos da Formação do Povo Brasileiro. Funpec, Ribeirão Preto, pp 93-112.

Mateu E, Comas D, Calafell F, Perez-Lezaun A, Abade A and Bertranpetit J (1997) A tale of two islands: Population history and mitochondrial DNA sequence variation of Bioko and Sao Tome, Gulf of Guinea. Ann Hum Genet 61:507518.

Mishmar D, Ruiz-Pesini E, Golik P, Macaulay V, Clark AG, Hosseini S, Brandon M, Easley K, Chen E, Brown MD et al. (2003) Natural selection shaped regional mtDNA variation in humans. Proc Natl Acad Sci USA 100:171-176.

Pante-de-Souza G, Mousinho-Ribeiro RC, Santos EMJ, Zago MA and Guerreiro JF (1998) Origin of the hemoglobin S gene in a northern Brazilian population: The combined effects of 
slave trade and internal migration. Genet Mol Biol 21:427430

Pereira L, Prata MJ and Amorim A (2000) Diversity of mtDNA lineages in Portugal: Not a genetic edge of European variation. Ann Hum Genet 64:491-506.

Pereira L, Macaulay V, Torroni A, Scozzari R, Prata MJ and Amorim A (2001) Prehistoric and historic traces in the mtDNA of Mozambique: Insights into the Bantu expansions and the slave trade. Ann Hum Genet 65:439-458.

Plaza S, Salas A, Calafell F, Corte-Real F, Bertranpetit J, Carracedo A and Comas D (2004) Insights into the western Bantu dispersal: mtDNA lineage analysis in Angola. Hum Genet 115:439-47.

Porto A (1938) Fundação da Cidade Paraense e Outros Aspectos da História do Brasil. Pongetti, Rio de Janeiro, 183 pp.

Rando JC, Pinto F, Gonzalez AM, Hernandez M, Larruga JM, Cabrera VM and Bandelt HJ (1998) Mitochondrial DNA analysis of northwest African populations reveals genetic exchanges with European, near-eastern, and sub-Saharan populations. Ann Hum Genet 62:531-550.

Ribeiro D (1995) O Povo Brasileiro. A Formação e o Sentido do Brasil. Schwarcz, São Paulo, 470 pp.

Ribeiro-dos-Santos AKC, Pereira JM, Lobato MR, Carvalho BM, Guerreiro JF and Santos SEB (2002) Dissimilarities in the process of formation of Curiau, a semi-isolated AfroBrazilian population of the Amazon region. Am J Hum Biol 14:440-447.

Ribeiro-dos-Santos AKC, Carvalho BM, Feio-dos-Santos AC and Santos SEB (2007) Nucleotide variability of HV-I in Afrodescendents populations of the Brazilian Amazon Region. Forensic Sci Int 167:77-80.

Rosa A, Brehm A, Kivisild T, Metspalu E and Villems R (2004) MtDNA profile of West Africa Guineans: Towards a better understanding of the Senegambia region. Ann Hum Genet 68:340-352.

Rozas J, Sánchez-Delbarrio JC, Messenguer X and Rosas R (2003) DNA Polymorphism analysis by the coalescent and other methods. Bioinformatics 19:2496-2497.

Salas A, Richards M, De La Fe T, Lareu MV, Sobrino B, Sánchez-Diz P, Macaulay V and Carracedo A (2002) The making of the African mtDNA landscape. Am J Hum Genet 71:1082-1111.

Salas A, Richards M, Lareu MV, Scozzari R, Coppa A, Torroni A, Macaulay V and Carracedo A (2004) The African diaspora: Mitochondrial DNA and the Atlantic slave trade. Am J Hum Genet 74:454-465.

Salles V (1988) O Negro no Pará sob o Regime de Escravidão. SECULT, Belém, 342 pp.

Salzano FM and Freire-Maia N (1970) Problems in Human Biology: A Study of Brazilian Populations. Wayne State University Press, Detroit, 200 pp.

Sambrook J, Fritsch EF and Maniatis T (1989) Molecular Cloning: A Laboratory Manual. New York, Cold Spring Harbor Press.

Santos SEB, Ribeiro-dos-Santos AKC, Meyer D and Zago MA (1996) Multiple founder haplotypes of mitochondrial DNA in Amerindians revealed by RFLP and sequencing. Ann Hum Genet 60:305-319.

Santos SEB, Rodrigues JD, Ribeiro-dos-Santos AKC and Zago MA (1999) Differential contribution of indigenous men and women to the formation of an urban population in the Amazon region as revealed by mtDNA and Y-DNA. Am J Phys Anthropol 109:175-180.

Schneider H, Guerreiro JF, Santos SEB, Weimer TA, Schneider MPC and Salzano FM (1987). Isolate breakdown in Amazonia: The blacks of the Trombetas river. Braz J Genet 10:565-574.

Schneider S, Roessli D and Excoffier L (2000) Arlequin: A Software for Population Genetic Data. Genetics and Biometry Laboratory, University of Geneva, Switzerland.

Shen P, Lavi T, Kivisild T, Chou V, Sengun D, Gefel D, Shpirer I, Woolf E, Hillel J, Feldman MW et al. (2004) Reconstruction of patrilineages and matrilineages of Samaritans and other Israeli populations from Y-chromosome and mitochondrial DNA sequence variation. Hum Mutat 24:248-260.

Silva-Junior WA, Bortolini MC, Schneider MP, Marredo A, Krishnamoorthy R and Zago MA (2006) mtDNA haplogroup analysis of Black Brazilian and Sub-Saharan populations: Implications for the Atlantic slave trade. Hum Biol 78:29-41.

Torres MM, Bravi CM, Bortolini MC, Duque C, CallegariJacques S, Ortiz D, Bedoya G, Groot de Restrepo H and Ruiz-Linares A (2006) A revertant of the major founder $\mathrm{Na}$ tive American haplogroup $\mathrm{C}$ common in populations from northern South America. Am J Hum Biol 18:59-65.

Torroni A, Schurr TG, Yang CC, Szathmary EJ, Williams RC, Schanfield MS, Troup GA, Knowler WC, Lawrence DN and Weiss KM (1992) Native American mitochondrial DNA analysis indicates that the Amerind and the Nadene populations were founded by two independent migrations. Genetics 130:153-162.

Torroni A, Schurr TG, Cabell MF, Brown MD, Neel JV, Larsen M, Smith DG, Vullo CM and Wallace DC (1993) Asian affinities and continental radiation of the four founding Native American mtDNAs. Am J Hum Genet 53:563-590.

Torroni A, Huoponen K, Francalacci P, Petrozzi M, Morelli L, Scozzari R, Obinu D, Savontaus ML and Wallace DC (1996) Classification of European mtDNAs from an analysis of three European populations. Genetics 144:1835-1850.

Vigilant L, Stoneking M, Harpending H, Hawkes K and Wilson AC (1991) African populations and the evolution of human mitochondrial DNA. Science 253:1503-1507.

Ward RH, Frazier BL, Dew-Jager K and Pääbo S (1991) Extensive mitochondrial diversity within a single Amerindian tribe. Proc Natl Acad Sci USA 88:8720-8724.

Watson E, Bauer K, Aman R, Weiss G, Von Heaseler A and Pääbo $\mathrm{S}$ (1996) mtDNA sequence diversity in Africa. Am J Hum Genet 59:437-444.

Watson E, Forster P, Richards M and Bandelt HJ (1997) Mitochondrial footprints of human expansions in Africa. Am J Hum Genet 61:691-704.

Yao YG, Kong QP, Bandelt HJ, Kivisild T and Zhang YP (2002) Phylogeographic differentiation of mitochondrial DNA in Han Chinese. Am J Hum Genet 70:635-651. Associate Editor: Francisco Mauro Salzano 